\title{
Digital entrepreneurship in Morocco: measurement model validation
}

\author{
Zakia Saoura $^{1 *}$, Ahmed Abriane ${ }^{1}$, and Aniss Moumen ${ }^{2}$ \\ ${ }^{1}$ LEREG, FSJESA, Ibn Zohr University, Agadir, Morocco \\ ${ }^{2}$ LES, ENSA, Ibn Tofail University, Kenitra, Morocco
}

\begin{abstract}
According to the 2017 Global Entrepreneurship Monitor report, there are 6.5 million adults aged 18-64 planning to start an entrepreneurial career by 2020 . However, the gap between attempt and effective creations remains one of the largest within Arab countries (40\% versus 9\%). Given these statistics, we ask the question about the profile of the Moroccan entrepreneur. In this paper, we opted for a quantitative research methodology on an exploratory sample. We distributed a questionnaire to a sample of eighty Moroccan entrepreneurs representing different regions of Morocco. The objective of our study is to validate a measurement scale of three dimensions: 1 / entrepreneurial motivations, 2 / skills, and 3/ behaviour in the Moroccan context. To do so, we present, in the first part, a literature review on digital entrepreneurship. Then, we establish a state of the art of entrepreneurship in Morocco. Then, we show our methodology. Finally, we reveal and discuss the results of our study.
\end{abstract}

\section{Introduction}

Growing at a higher speed for some time, the phenomenon of digital entrepreneurship has not been sufficiently addressed by the scientific community. Some definitions of the concept do exist but need to be discussed [1].

Many researchers are interested in the question of "why?" to determine the personal traits of the entrepreneur and his entrepreneurial motivations [2]. Entrepreneurs exhibit attributes that are more pronounced in them than in the general population. These characteristics make up an "average entrepreneurial profile" [3]. However, the personal characteristics of digital or traditional entrepreneurs can vary like any other individual.

For example, the results of studies conducted to compare between traditional and digital entrepreneurs show that most digital entrepreneurs are men, aged between 25 and 45, married in most cases [3]. These entrepreneurs are willing to adapt, to change, open to the opportunities that change brings and hold a particular belief in the importance of research and technology in the creation and development of new businesses. They are also more educated than those in traditional firms [4].

According to [4], the age of digital entrepreneurs is comparable to that of traditional entrepreneurs, still, in the case of gender, there is a significant difference: female participation

* Corresponding author: zakia.saoura@edu.uiz.ac.ma 
is lower in technology companies. Other authors [5] point out that it would be essential to do more research to understand why there are few women entrepreneurs in the technology sectors.

In the Moroccan context, we have seen that the question that remains largely unanswered today is:

\section{HOW THE DIGITAL ENTREPRENEUR DIFFERS FROM THE TRADITIONAL ENTREPRENEUR?}

Our research, in its entirety, aims to answer this question, but we cannot answer it without validating the measurement scales that are the subject of this study.

In that way, we conducted a quantitative study based on a questionnaire distributed to a sample of eighty digital and traditional entrepreneurs from Morocco. First, we start by establishing a literature review dealing with the traditional entrepreneur and the digital entrepreneur. Then we identify the themes of our questionnaire. Thereafter we outline the methodology adopted. Finally, we present the results obtained from our research.

\section{Digital Entrepreneurship: literature review}

\subsection{Key Concepts}

\subsubsection{Entrepreneurship}

[6] defined entrepreneurship as "an activity involving the discovery, evaluation, and exploitation of opportunities to introduce new goods and services, new organisational structures, new markets, processes, and materials, by means that may not have existed before". Indeed, we cannot talk about entrepreneurship without innovation, and digital entrepreneurship implies a strong presence of innovation in projects.

\subsubsection{The digital entrepreneur/web entrepreneur}

When we say "digital", we often think of "online". We also think of electronic, symbolized by the "e" [7]. The digital entrepreneur is an entrepreneur who mobilizes resources and skills to develop an activity on the web. He commercializes goods and, or services via digital distribution channels [8].

\subsubsection{The start-up}

The word start-up covers a wide range of realities. It is poorly or not at all defined. In common sense, it refers in a vague way to the vast world of new technologies. The Start-up concept brings together three ideas: small size, new technologies, and a new beginning, coupled with the need for rapid growth. However, none of these dimensions, taken in isolation, is enough to make a company a start-up [9].

On the managerial level, there is ambiguity about the definition of start-ups. However, most researchers retain some criteria to define them, such as:

- the creation date of the start-up must be less than five years,

- the investment in research and development, financing by venture capitalists,

- the innovative character of the project,

- $\quad$ and the use of technologies as well as the speed of either growth or decline [10]. 


\subsubsection{Digital entrepreneurship}

A digital company is an entity that carries a digital economy. It relies on new technologies to be more efficient, to conquer new markets, to better know its customers, and to better interact with them. Thus, digital companies aim to serve customers better [11]. A company is digital if it meets at least the following criteria:

- The internet: the company must be connected to the internet to always interact with customers.

- Social networks: it should be present on social networks.

- Mobility: mobility carried by smartphones and other tablets is a crucial component.

- Dematerialization: digital information circulates much faster than paper information.

- Collaborative work: the objective here is to move from a hierarchical organization to cooperative operations.

- Predictive technologies (Big Data): "Big Data" is the ability to manage all the structured and unstructured data within a company, so that it can gain agility and competitiveness.

[12] defines a High-Tech company as a company that uses or invests in an emerging or rapidly evolving technology as a critical factor in developing its product, production, or marketing strategy.

In their article, published in September 2019, [1] conducted a review of existing definitions on this topic in the literature to give a new transparent and functional definition of digital entrepreneurship.

Digital entrepreneurship is a form of entrepreneurship that consists in seizing opportunities exclusively on the internet, via new digital technologies, for the creation of totally or partially electronic business, whatever the nature of the product or service offered, if it brings a purely digital added value for the consumer [1].

\subsubsection{The difference between a start-up and a company}

According to Oussama Ammar ${ }^{\dagger}$, a start-up is a social entity that looks for a business model, at the same time, an enterprise is a social entity that exploits and optimizes an already existing business model. Thus, the fundamental difference is that a company executes and optimizes a business model that works, while a start-up finds one.

\subsection{Comparison between the traditional and digital entrepreneur in the literature}

The concept of digital entrepreneurship is unanimously perceived as a form of entrepreneurship since it pursues the same objectives as traditional entrepreneurship: seizing opportunities in an environment to create business [1]. This environment corresponds to the internet and new digital technologies that also seem to constitute a vital element of digital entrepreneurship. Indeed, unlike multi-channel companies, also called "Brick \& Clicks", which use online services to reinforce their traditional store, the digital entrepreneur has no physical store presence and sells his products or services exclusively via the internet [13]. According to [10], digital entrepreneurship seems to combine the characteristics of traditional

\footnotetext{
† Oussama Ammar is an entrepreneur, business angel and advisor born on September 25, 1986, in Beirut, Lebanon. In 2013, he founded the business incubator The Family with Alice Zagury and Nicolas Colin.
} 
entrepreneurship with the specifics of the digital world, with a greater sensitivity to risk, creativity, or agility.

The concept of the entrepreneur has evolved. In the 16th and 17th centuries, the entrepreneur was an individual who engaged in speculative activities [14]. Today, digital technology recreates and reorganizes business management and team management. Business is being reinvented. It is not just a simple channel within a strategy; it becomes an entire organization. We are talking about tools and processes. Digital tools bring actual speed in terms of management and relationships with partners [15].

A survey conducted on the Moroccan entrepreneur by [15] to validate a repository of entrepreneurial skills showed that the entrepreneurs interviewed placed much emphasis on the digital skills mobilized and considered as transversal. Indeed, with increasingly fierce competition and in the era of digitalization, digital skills are increasingly mobilized. Most of the surveyed digital entrepreneurs proclaim their differentiation from competitors thanks to digital skills, which improves their e-reputation and raises their revenues.

Nevertheless, the most notable point of contention concerns the nature of the product or service. Indeed, some authors associate digital entrepreneurship with creating and forming companies offering exclusively digital goods and services. In contrast, other authors think that digital entrepreneurship can be about digitalising a part or all the entrepreneurial process. In other words, products and services can be digital as well as physical [1]. Thus, [16] demonstrated how a company that sells physical products such as Amazon could not be excluded from the field of digital entrepreneurship.

In their study of digital entrepreneurship, [17] propose a typology of digital entrepreneurship corresponding to degrees of digitalization: light, moderate and extreme digital entrepreneurship according to different criteria: digital sales, digital distribution of product or service, digital marketing, the digital nature of good or service, digital interactions with the main external stakeholders in the value chain, and the digital potential of the business's internal virtual activities.

In their collective work "Les entrepreneurs des générations $\mathrm{X}$ et $\mathrm{Y}$ ", [18] conducted a comparison study between entrepreneurs X (38 to 47 years old), Y (21 to 37 years old), and $\mathrm{Z}$ (less than 21 years old) in Quebec and France. Among the main results of their study, they found that the new generations seem to differ from their predecessors. Their values and outlook on society, their aspirations, and their deep motivations make them a completely different group. However, when asked, "Are there differences between the generations? "one participant responded, "It is the period where we are that differs mostly between generations, not the generation you belong to".

\section{Research Methodology}

The objective of our analysis is to validate a measurement model in the Moroccan context. In this section, we will first present the sample chosen for the questioning. We will then describe the data collection method. Finally, we will specify our measurement scales.

\subsection{Description of the sample}

The sample includes eighty entrepreneurs, 53\% digital entrepreneurs and $47 \%$ traditional entrepreneurs. The following table summarizes the main descriptive characteristics of each sub-sample. 
Table 1. Characteristics of the sample

\begin{tabular}{|c|c|c|}
\hline & Traditional entrepreneur & Digital entrepreneur \\
\hline Gender & $66 \% \mathrm{M} ; 34 \% \mathrm{~F}$ & $82 \% \mathrm{M} ; 18 \% \mathrm{~F}$ \\
\hline Age & $\begin{array}{c}69 \% \text { between } 25 \text { and } 35 ; \\
21 \% \text { over } 35 ; \\
10 \% \text { between } 18 \text { and } 25\end{array}$ & $\begin{array}{c}55 \% \text { between } 25 \text { and } 35 ; \\
24 \% \text { over } 35 ; \\
21 \% \text { between } 18 \text { and } 25\end{array}$ \\
\hline Family situation & $\begin{array}{l}59 \% \text { single } \\
38 \% \text { married } \\
3 \% \text { divorced }\end{array}$ & $\begin{array}{l}55 \% \text { single } \\
42 \% \text { married } \\
3 \% \text { divorced }\end{array}$ \\
\hline Level of education & $\begin{array}{c}69 \% \text { bac }+5 \\
14 \% \text { bac }+3 \\
10 \% \text { bac or lower } \\
7 \% \mathrm{PhD}\end{array}$ & $\begin{array}{c}70 \% \text { bac }+5 \\
24 \% \text { bac }+3 \\
6 \% \mathrm{PhD}\end{array}$ \\
\hline
\end{tabular}

\subsection{Development of the questionnaire}

Our questionnaire aims at collecting entrepreneurial motivations, skills, and behaviour. To do this, we built our questionnaire based on previous research cited earlier in the literature review [19], [20], [21], [15] and [18].

We shared the questionnaire with the respondents through the internet (social and professional networks, emailing). At the end of this data collection campaign, we collected 87 questionnaires, and we retained 80 for analysis, i.e., $92 \%$ (several questionnaires collected were not complete, which led us not to consider them).

\subsection{Definition of variables}

Our analysis considers three variables: motivations, skills, and behaviour of the traditional and digital entrepreneurs. The table provides a summary of all the variables used in this study.

Table 2. Overview of used variables

\begin{tabular}{|c|c|c|}
\hline & variable & $\begin{array}{c}\text { Definition et measurement } \\
\text { of the variable }\end{array}$ \\
\hline \multirow{3}{*}{$\begin{array}{c}\text { Variables expressing } \\
\text { motivations, skills, and } \\
\text { behaviour, }\end{array}$} & Entr_motiv & Entrepreneurial motivations \\
\hline & skills & Skills \\
\hline & Beh_work & Behaviour at work \\
\hline
\end{tabular}

\subsection{Reliability of the measurement scale}

To ensure the internal reliability of the measurement scale thus obtained, we used Cronbach's alpha, which is an indicator that measures the reliability of the various items that are supposed to contribute to measuring a phenomenon. The factor is reliable if the Cronbach's alpha $>0.6$. Thus, according to [22], the factor is acceptable if Cronbach's alpha $>0.7$. 
Also, to check the factor structure [23], the Kaiser-Meye-Olkin (KMO) sampling adequacy indices are quite adequate. Its measure should be acceptable and have a value greater than 0.60 , thus reflecting the intercorrelation of the variables. Indeed, the use of the Bartlett sphericity test is also essential. It allows us to test the null hypothesis of a unit matrix.

\section{Results and discussion}

It should be noted that all the measurement scales used are 5-point Likert scales ranging from 1 "you do not possess at all" to 5 "you possess completely". In doing so, we based ourselves on the model established and statically validated by [24].

\subsection{Measuring entrepreneurial motivations}

In the field of entrepreneurship, many research studies have proposed items to measure entrepreneurial motivations. Following the objective of our research, we focused on the research works of [14], [3], and [18], which allowed us to identify sixteen items to measure entrepreneurial motivations.

The principal component factor analysis performed on the entrepreneurial motivation's variable allowed us to explain $65.8 \%$ of the variance with a KMO of 0.920 , Barlett significant and a Cronbach's alpha of 0.947 . According to the criteria for the reliability of the measurement scale described above, we conclude that the measurement scale for entrepreneurial motivations is reliable.

\subsection{Measurement of competences}

To operationalise the competency variable, we based ourselves largely on the model of [3], as well as the two research works of [19] and [18]. Moreover, in the Moroccan context, we drew on the empirical work of [21] and [15]. Thus, we retained eleven items for this dimension.

The principal component factor analysis performed on the skills variable allowed us to explain $64.5 \%$ of the variance with a KMO of 0.913, Barlett significant and a Cronbach's alpha of 0.911 . According to the criteria of the reliability of the measurement scale described above, we conclude that the competency measurement scale is reliable.

\subsection{Measuring behaviour}

As argued in the literature review of this paper, the last dimension refers to the work behaviour of digital and traditional entrepreneurs. In this study, we focused on the survey conducted by [18], which proposed ten items to measure the behaviour of different entrepreneurs.

The principal component factor analysis performed on the behaviour variable allowed us to explain $52.6 \%$ of the variance with a KMO of 0.806 , Barlett significant and a Cronbach's alpha of 0.822 . According to the criteria of the reliability of the measurement scale described above, we conclude that the behavioural measurement scale is reliable.

\section{Conclusion}

In our study, we validated the measurement scales of three variables: entrepreneurial motivations, skills, and behaviour of traditional and digital entrepreneurs in the Moroccan context. 
Regarding future research perspectives, we believe that a comparison study between traditional and digital entrepreneurs on a larger and homogeneous sample will follow this research work.

\section{References}

1. W. Bensaid and H. Azdimoussa, "l'entrepreneuriat digital : revue de littérature et nouvelle définition” Rev. Int. Mark. Manag. Strat., vol. 1, no. 3, p. 14, (2019).

2. M. Ndour, "L'évolution du business model de l'entreprise sociale, le cas des entreprises des TIC : une étude comparative de cas France/Sénégal," Université Paris Descartes et Université Gaston Berger, (2017).

3. Y. Gasse, "Les entrepreneurs des secteurs technologiques : leur profil, leurs motivations et leurs actions," Manag. Avenir, vol. 42, no. 2, p. 247- 261, (2011).

4. C. Borges, G. Simard, and L. J. Filion, "Entrepreneuriat technologique Résultats de recherche sur la création d'entreprises technologiques au Québec," HEC Montr., p. 42, (2005).

5. Christensen Patrizia V., Ulhøi John P., and Neergaard Helle, "The Entrepreneurial Process in High-tech and Knowledge-based Sectors in Denmark," LOK Res. Cent., no. 3, p. 26, (2001).

6. T. Verstraete, "Entrepreneuriat : modélisation du phénomène,” Rev. L'Entrepreneuriat, vol. 1, no. 1, p. 5, (2001).

7. P. Ledent, Entreprendre en 2016 : devenir un aventurier 4.0. EdiPro, p. 194, (2016).

8. C. Headly et A. Maalaoui, La boite à outils du digital entrepreneur. Dunod, p.192, (2012).

9. J.-L. Beffa, Se transformer ou mourir : les grands groupes face aux start-ups, Editions du seuil. p. 160, (2017).

10. S. Bouhaj and R. Jahidi, "contributions du capital client comme déterminant de réussite des start-up au Maroc: intérêt théorique et méthodologique," vol. 3, p. 18, (2018).

11. A. A. Boyarm, L'entreprise numérique africaine, Editions Céprodif. p. 179, (2018).

12. J. S. Park, "Opportunity recognition and product innovation in entrepreneurial hi-tech start-ups: a new perspective and supporting case study," Technovation, vol. 25, no. 7, pp. 739-752, (2005).

13. Y. Xing and D. B. Grant, "Developing a framework for measuring physical distribution service quality of multi-channel and 'pure player' internet retailers," Int. J. Retail Distrib. Manag., vol. 34, no. 4/5, pp. 278-289, (2006).

14. A. Fayolle and L. J. Filion, Devenir entrepreneur : Des enjeux aux outils, Édition Village Mondial. Paris: Pearson, (2006).

15. R. Aallali and H. drissi, "Quel référentiel de compétences transversales pour l'entrepreneur de la nouvelle génération? Cas des PME marocaines,' (2018), p. 26.

16. T. Kollmann, "What is E-Entrepreneurship? Fundamentals of company founding in the net economy," Int J Technol. Manag., vol. 33, (2006).

17. C. Hull, Y.-T. Hung, N. Hair, V. Perotti, and R. Demartino, "Taking advantage of digital opportunities: A typology of digital entrepreneurship," IJNVO, vol. 4, pp. 290 303, (2007).

18. M. Tremblay, M. Pelé, G. A. Dokou, and Y. Gasse, Les entrepreneurs des générations X et Y, Ellipses. p. 240, (2019). 
19. C. S. Tarres, A. P. Melendez, and A. R. D. A. Obra, "The influence of entrepreneur characteristics on the success of pure dot.com firms," Int. J. Technol. Manag., vol. 33, no. 4, p. 373, (2006).

20. D. Guerraoui and N. Affaya, l'élite économique marocaine - Etude sur la nouvelle génération d'entrepreneurs, L'Harmattan. p. 262, (2009).

21. C. Loué and I. Majdouline, "Les compétences de l'entrepreneur marocain: validation quantitative d'un référentiel," Rev. Int. PME, vol. 28, no. 2, pp. 159-189, (2015).

22. J. C. Nunnally and I. H. Bernstein, "Psychometric Theory», ed.3. New York: McGraw Hil, (1994).

23. D. W. Stewart, "The Application and Misapplication of Factor Analysis in Marketing Research,” J. Mark. Res., vol. 18, no. 1, p. 51-62, (1981).

24. Y. Gasse and M. Tremblay, "Sensibilisation à l'entrepreneuriat: construction et validation empirique d'un outil pratique.” Université Laval, (2005). 